現場ノート

\title{
簡易蒸留水製造装 置
}

\section{堀 内 敏 雄*}

\section{1 まえがき}

化学分析者に蒸留水は血液である.当所で核従来市 販の蒸留水製造装置を用いたり，イオン交換樹脂による 小型純水製造装置にたよっていたが，それだけでは蒸留 水が不足がちなので, 現在では市販の装置の購入をや め各室ごとに簡易蒸留水製造装置を自製して使用してい る.この装置㳊製作費が安いうえに, ある程度の水圧変 化にも陾兑, 廃熱水は水浴として利用できるなどの利点 があるので紹介する。

\section{2 装置の説明}

本装䈯は図に示すように，4l の丸底フラスコの中に 電熱線芯組文込えだもので, 内部が見えるので安全操業

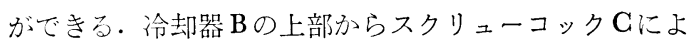
って調節された水がフラスコ A内にはいる.フラスコ内 の廃熱水は $\mathrm{G}$ 管を通って浴そう $\mathrm{E}$ にはいり水浴として利 用できる・長期使用によりフラスコにスケールがたまっ たときは，スクリューコックDを開け，希塩酸で洗浄す る.各接続部はゴムせんとビニル管を用いたが，高温に さらされる (4),(5),(6) のビニル管は針金で固定しておく とよいが，シリコンゴム管を用いるとよいであろう。ま た電熱線と銅線の接続はビス止めスリーブか小型のボル トナットで結線し, 沸騰により振動で短絡するのを防ぐ ため銅線部はガラス管で被覆して用いるとよい.

\section{3 本装置の能力}

本装置で作った蒸留水は, 蒸発残さが $1 \mathrm{mg} / 1 \mathrm{l}$ 以下 で，一般の分析室ではじゅうぶんな純度のものが得られ

* 宇部興産株式会社宇部窒素工場 : 山口県宇部市大字 小串

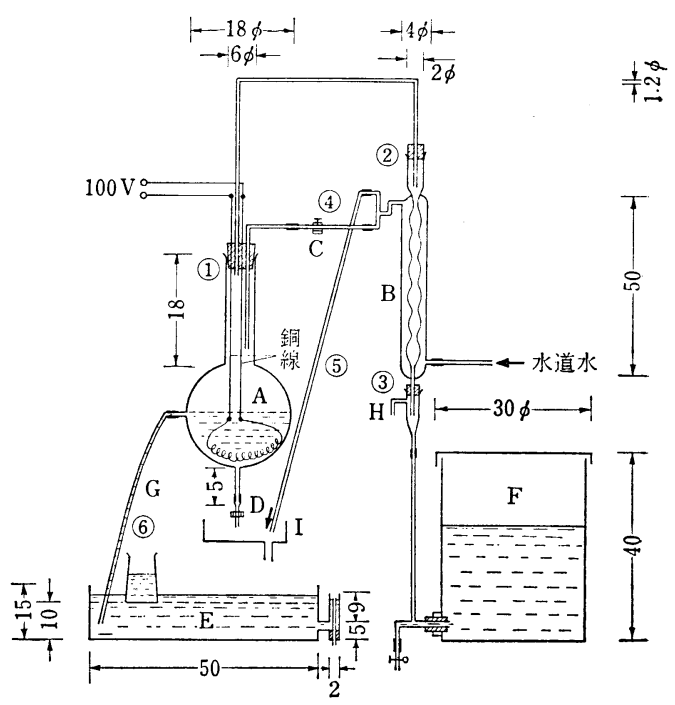

簡易蒸留水製造装置 (単位: $\mathrm{cm}$ )

$\mathrm{A}$ : 雚留フラスコ,ヒーターは直径 $2 \mathrm{~cm}$ に巻いた $1 \mathrm{~kW}$ のニクロム線; $\mathrm{B}$ : 球入り冷却器; $\mathrm{C}$ ：添加水量を調節するスクリニーコック； D : スクリューコック, 内部洗净時にのみ使用, 普段は閉めておく; $E$ : 廃熱水利用の水浴, 必要に応じて底部を加熱する; $F$ : 苲留水の眝そ う； $\mathrm{G}$ : 蒸留フラスコ内の液面保持のための廃熱水管; $\mathrm{H}$ : 息抜き部; I : 冷却水の察衰バット; (1),(2),(3)：ゴムせん; (4),(5),(6)：ビニル管

る. また製造能力は気温 $24^{\circ} \mathrm{C}$, 水温 $20^{\circ} \mathrm{C}$, 気圧 765 $\mathrm{mmHg}$ のもとで，G管を閉め, コック $\mathrm{C}$ を調節して留 出量と同程度の水を補給した場合には, 約 $3.2 l / \mathrm{hr} の$ 能力があり， G管を開けたままでコック $\mathrm{C}$ を調節して留 出量の約 3 倍の水を補給した場合には約 $2.9 l / \mathrm{hr}$ の能 力がある. 本装置は製作費が安いうえに廃熱水は水浴と して利用でき，しかも製造能力も大きいなどの利点があ る.

終わりに，本稿に助言をいただいた服部 博氏に謝意 を表します。 